\title{
EFFECT OF CHLORIDE IONS ON THE PASSIVE LAYER FOR THREE AL-ALLOYS AT PH=9
}

\author{
Naema A. Hikmat*, Ahlam M. Farhan** and Rana A. Majed*** \\ * Department of Chemistry, College of Science, University of Baghdad. \\ ** Department of Chemistry, College of Science for Woman, University of Baghdad. \\ *** Department of Materials Engineering, University of Technology.
}

\begin{abstract}
This work involves the study of the effect of chloride ion on the passive layer which is formed on the surface of three aluminium alloys (Al-Cu-Mg), (Al-Mg), and (Al-Zn). The concentrations of chloride ion used were $\left(1 \times 10^{-3}, 1 \times 10^{-2}, 0.1 \mathrm{~mol} . \mathrm{dm}^{-3}\right)$. The study was performed in $1 \times 10^{-5}$ mol.dm ${ }^{-3} \mathrm{NaOH}$ solution which was corresponded to $\mathrm{pH}$ value of (9). The data of polarization behaviour were calculated by Tafel extrapolation method and the comparison of this data in the absence and presence of chloride ions were discussed.
\end{abstract}

\section{Keyword: Effect of Chloride ions, Aluminium alloys, Corrosion of Al alloy, Polarization behavior.}

\section{Introduction}

Aluminium and most aluminium alloys have good corrosion resistance in natural atmospheres, fresh water, seawater, many soils, many chemicals and their solutions, and most foods. This resistance to corrosion is the result of the presence of a very thin, compact, and adherent film of aluminium oxide on the metal surface ${ }^{(1)}$.

Whenever a fresh surface is created by cutting or abrasion and is exposed to either air or water, a new film forms rapidly, growing to a stable thickness. The film formed in air at ambient temperature is $\approx 5 \mathrm{~nm}\left(50 \mathrm{~A}^{\circ}\right)$ thick. The thickness increases with increasing temperature and in the presence of water.

The oxide film is soluble in alkaline solutions and in strong acids, with some exceptions, but is stable over a $\mathrm{pH}$ range of $(\approx 4.0$ to 9.0$)$.

Aluminium alloys are used in storing, processing, handling, and packaging of a variety of chemical products.

They are compatible with most dry inorganic salts. Within the passive $\mathrm{pH}$ range, they resist corrosion in solutions of most inorganic chemicals but are subjected to pitting in aerated solutions, particularly of halides ${ }^{(1)}$.

There are many investigations about aluminium and its alloys in chloride solution at various values of $\mathrm{pH}$. Nisancioglu et.al (2) measured of the critical pitting potential of aluminium and its alloys in chloride media by using current controlled, potential controlled, and open circuit methods.

Also they studied $^{(3)}$ the corrosion behaviour of aluminium in chloride solutions at potentials below the critical pitting potential by using potentiodynamic method and steady state polarization data.

Sanad et. al. ${ }^{(4)}$ studied the corrosion behaviour of aluminium and $\mathrm{Al}-\mathrm{Mg}$ alloys by means of weight-loss measurements and potentiokinetic experiments at different temperature $\left(30,50,70\right.$ and $\left.100^{\circ} \mathrm{C}\right)$ in $32.7 \mathrm{~g} / \mathrm{L}$ sodium chloride. Bogustaw ${ }^{(5)}$ studied the electrochemical behaviour of $\mathrm{Al}-\mathrm{Mg}$ alloys. Stationary potentiodynamic and potentiodynamic studies were performed on synthetically obtained $\mathrm{Al}_{8} \mathrm{Mg}_{5}$ samples.

A tendency for passivity in electrolytes of $\mathrm{pH}$ value between 4 and 10 is a limited potential ranges. For high $\mathrm{pH}$ values the $\mathrm{Al}_{8} \mathrm{Mg}_{5}$ compound was passive over the entire range of anodic potentials. In the corrosion and anodic polarization of $\mathrm{Al}_{8} \mathrm{Mg}_{5}$ magnesium dissolution is favoured rather than the formation of $\mathrm{Al}^{+3}$ and $\mathrm{Mg}^{+2}$ in stoichiometrically equivalent amounts.

Lunarska et.al ${ }^{(6)}$ studied the changes in morphology and chemical composition of corrosion on the surface of three powder metallurgy $\mathrm{AlZnMg}$ alloys containing 8.8 to $12.5 \% \mathrm{Zn}, 2.4$ to $2.5 \% \mathrm{Mg}$ and 1.2 to $1.5 \mathrm{Cu}$ after their exposure to deaerated $3.5 \% \mathrm{NaCl}$ solutions of $\mathrm{pH} 1,7$ and 13 at room temperature in a wide range of applied 
potentials, using scanning electron microscopy (SEM) and energy dispersive spectroscopy (EDS) techniques.

Alavi et.al ${ }^{(7)}$ studied the conditions of crevices for $\mathrm{Al}-\mathrm{Zn}-\mathrm{Mg}$ alloy in $0.6 \mathrm{M} \mathrm{NaCl}$ such as $\mathrm{pH}$, potential and chloride concentration. They observed that a possible explanation is that chloride-containing species are being formed, and as a result hydroxyl ions being librated according to a reaction:

$\mathrm{Al}+3 \mathrm{H}_{2} \mathrm{O}+\mathrm{xCl}^{-} \leftrightarrow \mathrm{Al}(\mathrm{OH})_{3-\mathrm{x}} \mathrm{Cl}_{\mathrm{x}}+1 \frac{1}{2} \mathrm{H}_{2}+\mathrm{xOH}^{-}$

Also they reported $\mathrm{pH}$ values of 7-9 in simulated crevices of $\mathrm{Al}$ alloy and they attributed it to the hydrolysis of $\mathrm{Al}^{3+}$ ions to $\mathrm{Al}_{2}(\mathrm{OH})_{4}{ }^{2+}$, which might be regarded as being similar to the effects of above equation.

Tomcsanyi and Co - workers ${ }^{(8)}$ studied the composition of the passive layer on aluminium and reformation of this layer during cathodic polarization by radiotracer and electrochemical methods in the presence of sulphate and chloride ions.

They discussed formation of hexacoordinated aluminium ion which forms different hydroxo complexes in neutral solution $(\mathrm{pH}=4-10)$.

$\mathrm{O}^{2-}$ ions are also formed in the solid phase by topochemical reaction to produce [Al $\left.\mathrm{O}_{x}(\mathrm{OH})_{y}\left(\mathrm{H}_{2} \mathrm{O}\right)_{z}\right]$ and then transforms in aqueous media to $\mathrm{Al}(\mathrm{OH})_{3}$.

Chloride ion is bonded chemically in the interface as an initial step of the formation of different mixed oxohydroxo- and chlorocomplexes according to the following formula:

$\mathrm{Al}\left[\mathrm{O}_{\mathrm{x}}(\mathrm{OH})_{\mathrm{y}}\left(\mathrm{H}_{2} \mathrm{O}\right)_{\mathrm{z}}\right]+\mathrm{Cl}^{-} \rightarrow \mathrm{Al}\left[\mathrm{O}_{\mathrm{x}}(\mathrm{OH})_{\mathrm{y}-1} \mathrm{Cl}\left(\mathrm{H}_{2} \mathrm{O}\right)_{\mathrm{z}}\right]+\mathrm{OH}^{-}$

$(\mathrm{AlOOH})_{4} * \mathrm{H}_{2} \mathrm{O}+\mathrm{Cl}^{-} \rightarrow(\mathrm{AlOOH})_{3} * \mathrm{AlOCl}_{*} \mathrm{H}_{2} \mathrm{O}+\mathrm{OH}^{-}$

$\mathrm{AlOOH}+\mathrm{Cl}^{-} \rightarrow \mathrm{AlOCl}+\mathrm{OH}^{-}$

$\mathrm{Al}(\mathrm{OH})_{3}+\mathrm{Cl}^{-} \rightarrow \mathrm{Al}(\mathrm{OH})_{2} \mathrm{Cl}+\mathrm{OH}^{-}$

Finally the $\left[\mathrm{AlCl}_{6}\right]^{3-}$ complex is produced.

Elboujdaini et.al ${ }^{(9)}$ studied the anodic behaviour of aluminium alloys (5083 and 6061) in aqueous chloride solution in the presence of sulphate ions by the linear sweep polarization technique and potential step method.

Saidman, Garcia, and Bessone ${ }^{(10)}$ studied the electrochemical behaviour of aluminium in $\mathrm{NaCl}$ solutions containing $\mathrm{In}^{3+}$ ions and the dissolution of Al-In and In-Al alloys using potentiostatic, galvanostatic and potentiodynamic techniques, complemented by SEM.

William and Co-workers ${ }^{(11)}$ studied the effect of chromate treatment on the corrosion of an $\mathrm{Al} / \mathrm{Cu}$ aircraft alloy with a galvanic corrosion aperture composed of two electrodes and a zero resistance ammeter. Combination of pure $\mathrm{Al}$, pure $\mathrm{Cu}$, and 2024 electrodes were immersed in $0.1 \mathrm{M} \mathrm{NaCl}$ solution, which was saturated with air, $\mathrm{O}_{2}$, or argon.

In this research the ability of chloride ions to destroy or penetrate the passive film in $\mathrm{NaOH}$ solution at $\mathrm{pH}=9$ were studied.

\section{Experimental Part}

Aluminium alloys were cut into square shape with $\left(1 \mathrm{~cm}^{2}\right)$ area, and made into electrode by pressing a copper wire into a hole on one side and then insulating all but one side with an epoxy resin as shown in Fig. (1).

The open side was polished mechanically to a mirror finish, rinsed in distilled water and stored in desiccators. The alloys were used $\mathrm{Al}-\mathrm{Cu}-\mathrm{Mg}, \mathrm{Al}-\mathrm{Mg}$, and $\mathrm{Al}-\mathrm{Zn}$ and the chemical analysis of these alloys was shown in Table (1).

The corrosion cell was of the usual type with provision for working electrode (pure metal and its alloys), auxiliary electrode (Pt electrode), and a Luggin capillary for connection with an SCE reference electrode.

The basic solution was $\mathrm{NaOH}$ solution with concentrations of $\left(1 \times 10^{-5}\right.$ mol. $\left.\mathrm{dm}^{-3}\right)$ which corresponding to $\mathrm{pH}$ value of (9), $\mathrm{NaOH}$ obtained from Ferak with M.wt 40 g. $\mathrm{mol}^{-1}$ and purity $>99.5 \%$, which prepare in distilled water (specific conductivity $1 \times 10^{-6}$ $\left.\mathrm{S} . \mathrm{m}^{-1}\right)$. Sodium chloride was used with three different concentrations $\left(1 \times 10^{-3}, 1 \times 10^{-2}\right.$, and $\left.0.1 \mathrm{~mol} . \mathrm{dm}^{-3}\right), \mathrm{NaCl}$ obtained from Fluka with M.wt 58.44 g. $\mathrm{mol}^{-1}$ and purity $99.5 \%$.

Electrochemical measurements were performed with a potentiostat (Corroscript) which was obtained from Tacussel (France) at a scan rate of 0.3 Volt per minute. The main results obtained were expressed in terms of the corrosion potentials $\left(\mathrm{E}_{\mathrm{corr}}\right)$ and corrosion current density $\left(i_{\text {corr }}\right)$ in addition to calculate the cathodic and anodic Tafel slopes by using extrapolation method as shown in Fig. (2). 


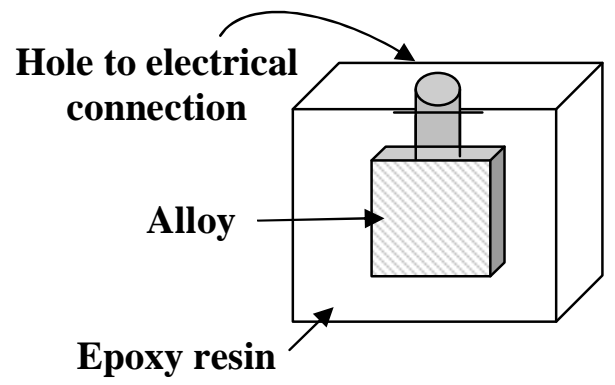

Fig. (1): The working electrode.

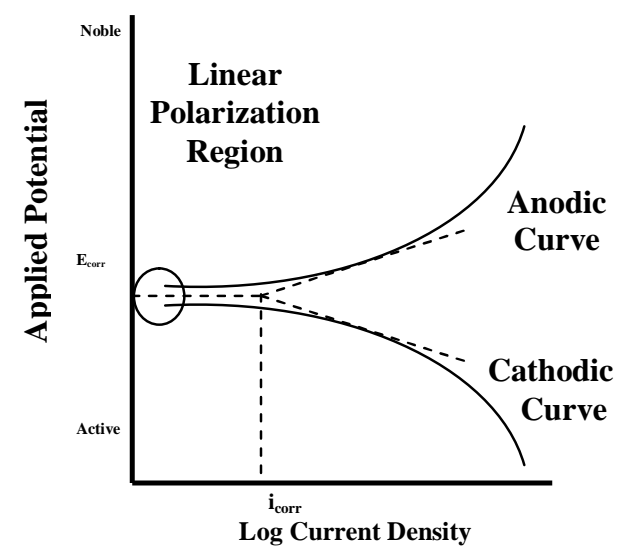

Fig. (2): Tafel extrapolation.

\section{Results and Discussion}

\section{Polarization Behaviour at $\mathrm{pH}=9$}

The various equilibria of $\mathrm{Al}-\mathrm{H}_{2} \mathrm{O}$ system has been studied by Pourbaix et. $\mathrm{al}^{(12)}$ in a potential versus $\mathrm{pH}$ diagram as shown in Fig. (3). This diagram indicates the theoretical circumstances in which aluminium should show corrosion (forming $\mathrm{Al}^{3+}$ at low $\mathrm{pH}$ value and $\mathrm{AlO}_{2}{ }^{-}$at high $\mathrm{pH}$ value), passivity due to hydragillite, i.e. $\mathrm{Al}_{2} \mathrm{O}_{3} .3 \mathrm{H}_{2} \mathrm{O}$ (at near-neutral $\mathrm{pH}$ values) and immunity (at high negative potentials).

The nature of the oxide actually varies according to temperature, boehmite $\left(\mathrm{Al}_{2} \mathrm{O}_{3} \cdot \mathrm{H}_{2} \mathrm{O}\right)$ is the stable for

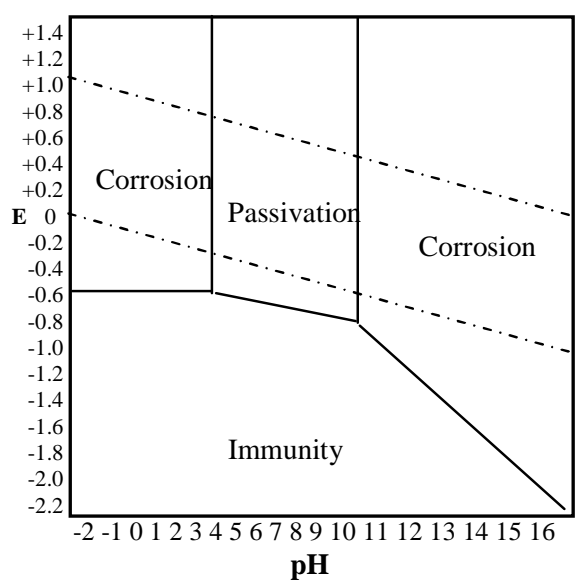

Fig. (3) : The corrosion immunity and passivation of aluminium at $25^{\circ} C^{(13)}$.
Study the polarization behaviour of three Al-alloys in $\mathrm{NaOH}$ solution at $\mathrm{pH}=9$ give the typical shape of polarization curve as shown in Fig. (4) for three alloys.

The difference among these three alloys was in the corrosion potential $\left(\mathrm{E}_{\text {corr }}\right)$ and corrosion current density $\left(\mathrm{i}_{\text {corr }}\right)$ as shown in Tables (2) to (4) in the absence the chloride ions in solution.

The section (abc) on the Fig.(4) represents the diffusion and transport of cations from the bulk solution to the metal / solution interface. Before electron transfer can occur the oxygen must be transported to the metal/solution interface by diffusion and by natural and forced convection and reduction of oxygen can occur as shown in the following reaction:

$$
\mathrm{O}_{2}+2 \mathrm{H}_{2} \mathrm{O}+4 \mathrm{e} \leftrightarrow 4 \mathrm{OH}^{-}
$$

Along the section (cde), the metal hydroxide is expected to be formed. The hydroxide soon dissociates into metal oxide $\left(\mathrm{Al}_{2} \mathrm{O}_{3}\right)$ on $\mathrm{Al}$ surface which behaves as a passive layer (protective film) according to the reaction :

$$
\mathrm{Al}^{3+}+3 \mathrm{H}_{2} \mathrm{O} \rightarrow \mathrm{Al}_{2} \mathrm{O}_{3}+6 \mathrm{H}^{+}
$$

The breakdown of passivity began at point (e) and continued along (ef), where along the section (ef) the metal hydroxide is expected to be formed according to the following reactions:

$$
\begin{aligned}
& \mathrm{Al}+3 \mathrm{OH}^{-} \rightarrow \mathrm{Al}(\mathrm{OH})_{3}+3 \mathrm{e} \\
& \mathrm{Al}(\mathrm{OH})_{3}+\mathrm{OH}^{-} \rightarrow \mathrm{Al}(\mathrm{OH})_{4}{ }^{-}
\end{aligned}
$$

The data that concerned to the polarization behaviour for three Al-alloys in the absence of chloride ions in solution are shown in the following sequence:

Corrosion potential(- $\left.\mathrm{E}_{\text {corr }}\right) \mathrm{Al}-\mathrm{Zn}>\mathrm{Al}-\mathrm{Mg}>\mathrm{Al}-$ $\mathrm{Cu}-\mathrm{Mg}$

Since the corrosion potential value for three alloys at $298 \mathrm{~K}$ was:
Al-Zn $\quad-1.72$ Volt
Al-Mg $\quad-1.61$ Volt
$\mathrm{Al}-\mathrm{Cu}-\mathrm{Mg} \quad-1.39$ Volt

Corrosion current density ( $\mathrm{i}_{\text {corr }}$ )

$\mathrm{Al}-\mathrm{Zn}>\mathrm{Al}-\mathrm{Mg}>\mathrm{Al}-\mathrm{Cu}-\mathrm{Mg}$

Passivity potential $\left(\mathrm{E}_{\mathrm{p}}\right)$

$\mathrm{Al}-\mathrm{Zn}>\mathrm{Al}-\mathrm{Mg}>\mathrm{Al}-\mathrm{Cu}-\mathrm{Mg}$

Passivity current density $\left(\mathrm{i}_{\mathrm{p}}\right)$

$\mathrm{Al}-\mathrm{Zn}>\mathrm{Al}-\mathrm{Mg}>\mathrm{Al}-\mathrm{Cu}-\mathrm{Mg}$ 


\section{Effect of chloride ions $\left(\mathrm{Cl}^{-}\right)$}

Addition of $1 \times 10^{-3}$ mol.dm $\mathrm{Cl}^{-}$to solution of $\mathrm{pH}=9$ don't destroy the passive layer as shown in Fig.(5), this effect may be due to the strength of bonding in the $\mathrm{Al}_{2} \mathrm{O}_{3}$ as protective film compared with bonding between Aluminium and chloride. The effect of this concentration of chloride ion shifts the $\left(\mathrm{E}_{\text {corr }}\right)$ values, for three alloys, to the active direction and the ( $\left.i_{\text {corr }}\right)$ to higher values.

Addition of $1 \times 10^{-2}$ mol.dm ${ }^{-3} \mathrm{Cl}^{-}$to the solution of $\mathrm{pH}=9$ destroy the passive layer for $\mathrm{Al}-\mathrm{Cu}-\mathrm{Mg}$ and $\mathrm{Al}-\mathrm{Mg}$ alloys and shifts the $\left(\mathrm{E}_{\text {corr }}\right)$ values to the noble direction and the ( $\left.i_{\text {corr }}\right)$ to lower values. While the Al-Zn alloy remains keeping with the passive film as shown in Fig.(6) in addition to shift the corrosion current density the higher vales and the corrosion potential in the active direction.

The presence of $0.1 \mathrm{~mol} . \mathrm{dm}^{-3} \mathrm{Cl}^{-}$in the solution destroy the aluminium oxide film which formed on the surface of three alloys at $\mathrm{pH}=9$ as shown in Fig.(7) where the curves represents the wide cathodic and anodic regions, in addition to the shifts of $\left(\mathrm{E}_{\mathrm{corr}}\right)$ values to the noble direction and ( $\left.i_{\text {corr }}\right)$ to the higher values.

Three or four halides ions are adsorbed on the passive film around the lattice cation $\left(\mathrm{Al}^{3+}\right)$, then they form a transitional complex with this cation and separate from the oxide ions in the lattice, but under the influence of the anodic field another cation comes up through the passive film to replace the dissolved one, and once the cation reaches the film-solution interface, it will find many halide ions with which it forms another transitional complex. So, once the process begins it will repeat itself at an accelerated rate due to the increased electrostatic field on this thinned point ${ }^{(14)}$.

The process can be formulated by four consecutive steps according to complex formation theory :

1- The halide ions are adsorbed on the passive film.

2- The chemical reaction between the adsorbed ions and $\left(\mathrm{Al}^{3+}\right)$ in the passive film lattice.

$\mathrm{Al}^{3+}\left(\right.$ in $\mathrm{Al}_{2} \mathrm{O}_{3} \cdot \mathrm{nH}_{2} \mathrm{O}$ lattice $)+\mathrm{Cl}^{-} \rightarrow \mathrm{Al}(\mathrm{OH})_{2} \mathrm{Cl}$ or

$\mathrm{Al}^{3+}$ (in $\mathrm{Al}_{2} \mathrm{O}_{3} \cdot \mathrm{nH}_{2} \mathrm{O}$ lattice) $+2 \mathrm{Cl}^{-} \rightarrow$ $\mathrm{Al}(\mathrm{OH})_{2} \mathrm{Cl}_{2}^{-}$
3- Thinning of the passive film by dissolution.

4- Direct interaction between the exposed metal and the halide ions to form transitional complexes which rapidly undergo hydrolysis:

$\mathrm{Al}^{3+}+4 \mathrm{Cl}^{-} \rightarrow \mathrm{AlCl}_{4}^{-}$

$\mathrm{AlCl}_{4}{ }^{-}+2 \mathrm{H}_{2} \mathrm{O} \rightarrow \mathrm{Al}(\mathrm{OH})_{2} \mathrm{Cl}+2 \mathrm{H}^{+}+3 \mathrm{Cl}^{-}$

\section{Tafel slopes (b)}

The hydrogen evolution reaction is of particular importance in corrosion for a number of reasons. Firstly, the reduction of $\mathrm{H}_{3} \mathrm{O}^{+}$ion in acid solutions or $\mathrm{H}_{2} \mathrm{O}$ molecule in neutral and alkaline solution is a common cathodic reaction for corrosion of metals in acid, neutral and alkaline solution. Secondly, hydrogen may pass into the lattice of certain metals and lead to embittlerment, and in the case of a number of alloys, particularly the high-tensile steels, it can lead to a catastrophic fracture $^{(12)}$.

Tables (2) to (4), in general, show that Tafel slopes are greater than expected $2.3 x(2 R T / F)\left(b=0.120\right.$ V.decade ${ }^{-1}$ or $\alpha=0.5$ at $25^{\circ} \mathrm{C}$ ) for the Volmer-Tafel mechanism.

The Tafel slopes greater than $2.3 x(2 R T / F)$ are usually regarded as anomalous since they cannot be predicted for any mechanism by the two well-known theoretical procedures, namely, the steady-state method and the quasiequilibrium approach, without making assumptions which are easily contestable ${ }^{(15)}$. During the preparation of the working electrodes to the corrosion test, exposure to air and therefore the electrodes undoubtedly had a thin oxide film on their surface before being introduced into the cell. It is clear, however, that the presence of a film can markedly influence the reduction process at the surface by affecting the energetic of the reaction at the double layer, or by imposing a barrier to charge transfer through the film, or both.

The first systematic explanation of anomalous Tafel slopes on oxide-covered electrodes was presented by Metikos ${ }^{(15)}$. He suggested that for a typical electrode reaction, e.g. hydrogen evolution reaction on a oxidecovered electrode, two potential energy barrier exist which are kinetically significant. First, the charge carriers, $\mathrm{H}_{3} \mathrm{O}^{+}$ions in the present case, must negotiate the barrier in the Helmholtz double layer to reach the reaction 
site at the oxide-electrolyte interface; and second, the electrons from the metal must negotiate the potential energy barrier within the oxide to reach the oxide-solution interface where the two charge carriers, $\mathrm{H}_{3} \mathrm{O}^{+}$and e, subsequently neutralize each other. This model is frequently referred to as the 'dual-barrier model'.

While in some cases, cathodic Tafel slopes $\left(b_{c}\right)$ values are less than $(0.120$ V.decade ${ }^{-1}$ ), where in chemical desorption step the adsorbed $\mathrm{H}$ atom diffuse about on the metal surface, either by threading their way through adsorbed water molecules or by pushing them aside, until two collide to form an $\mathrm{H}_{2}$ molecule which escapes into the solution. This chemical step will be independent of overpotential, since charge transfer is not involved, and the rate will be proportional to the concentration or coverage $\theta_{\mathrm{H}}$ of adsorbed $\mathrm{H}_{\mathrm{ads}}$ and may occur at coverage that range from very small to almost complete. If the discharge process is followed by a ratedetermining step involving chemical desorption, the expected value of the cathodic Tafel slope should be (-0.03 V.decade $\left.{ }^{-1}\right)$.

On the other hand, the electrochemical desorption step is far more complex since it involves reaction between an adsorbed $\mathrm{H}$ atom, a hydrated proton $\mathrm{H}_{3} \mathrm{O}^{+}$and an electron, and for desorption to occur the proton must discharge onto a hydrogen atom adsorbed on the metal surface.

Under these circumstances the probability of collision well is low unless the coverage $\theta_{\mathrm{H}}$ is high. When electrochemical desorption becomes the rate-determining step for hydrogen evolution reaction (h.e.r) on the cathode, the expected value of $b_{c}$ will be $(-0.05$ V.decade ${ }^{-1}$ ).

\section{Effect of Temperatures (T)}

The effect of temperature is complex. The more general effects may, however, be summarized as follows: (a) the velocity of corrosion reactions is greater at increased temperatures, (b) temperature changes may affect solubility of corrosion products or shift the position of such equilibria, (c) gases are less soluble at increased temperature, an effect which is, however, partly offset by greater diffusion rates and $(d)$ modification of $\mathrm{pH}$ value. This last effect is bound up with the previous two and is mainly of importance in affecting the form and distribution of corrosion products.

The overall effect is that corrosion is usually more rapid at higher temperatures, the corrosion product being often more objectionable in nature. There are, however, exceptions to this generalization and the increased rate of reaction at high temperature can sometimes be put to good advantage when corrective measure are being applied.

Generally, in the absence of chloride ions in solution, Tables (2) to (4) show that the increasing of temperature shift corrosion potential $\left(\mathrm{E}_{\text {corr }}\right)$ to the noble direction, and corrosion current density $\left(\mathrm{i}_{\text {corr }}\right)$ to the higher values, i.e., increase the rate of reaction, this due to increase the kinetic energy of ions and then increase of transport from and to electrodes and increase the reaction which occurs at electrodes. While in the presence of chloride ions in solution gives different behavior with increasing temperature. 
Table (1)

The analytical compositions of Al-Zn alloy which useful in this search.

\begin{tabular}{|c|c|c|c|c|c|c|c|c|c|c|}
\hline $\begin{array}{c}\text { Element } \\
\text { wt\% Alloy }\end{array}$ & $\mathbf{Z n}$ & Mg & $\mathrm{Cu}$ & $\mathrm{Cr}$ & $\mathrm{Fe}$ & $\mathbf{S i}$ & $\mathbf{T i}$ & Mn & $\mathbf{N i}$ & Al \\
\hline $\mathrm{Al}-\mathrm{Cu}-\mathrm{Mg}$ & 0.099 & 1.298 & 4.288 & 0.008 & 0.187 & 0.222 & 0.023 & 0.469 & 0.004 & Bal. \\
\hline Al-Mg & 0.003 & 2.413 & 0.049 & 0.013 & 0.212 & 0.239 & 0.005 & 0.008 & 0.005 & Bal. \\
\hline Al-Zn & 6.000 & 0.002 & 0.031 & 0.001 & 0.087 & 0.180 & 0.003 & 0.003 & 0.007 & Bal. \\
\hline
\end{tabular}

Table (2)

Values of corrosion potentials $E_{\text {corr }}$,corrosion current densities $i_{\text {corr }}$ cathodic and anodic Tafel slopes $\left(b_{c}\right.$ and $\left.b_{a}\right)$,cathodic and anodic transfer coefficients $\left(\alpha_{c}\right.$ and $\left.\alpha_{a}\right)$, passivity potentials $E_{p}$, and passivity current densities $i_{p}$, for the polarization of $\mathrm{Al}-\mathrm{Cu}$-Mg alloy in aerated $1 \times 10^{-5}$ mol.dm ${ }^{-3} \mathrm{NaOH}$ solution in absence and presence of chloride ions at four temperatures.

\begin{tabular}{|c|c|c|c|c|c|c|c|c|c|}
\hline \multirow[b]{2}{*}{ Medium } & \multirow{2}{*}{$\begin{array}{c}\mathbf{T} \\
(\mathbf{K})\end{array}$} & \multicolumn{2}{|c|}{ Corrosion } & \multicolumn{2}{|c|}{ b $\left(\right.$ V.decade $\left.^{-1}\right)$} & \multicolumn{2}{|c|}{$\alpha$} & \multicolumn{2}{|c|}{ Passivity } \\
\hline & & $\begin{array}{l}-E_{\text {corr }} \\
(V)\end{array}$ & $\begin{array}{c}i_{\text {corr }} / 10^{-6} \\
\text { A.cm } \\
-2\end{array}$ & $-b_{c}$ & $+b_{a}$ & $\boldsymbol{\alpha}_{\mathrm{c}}$ & $\alpha_{a}$ & $\begin{array}{l}-E_{p} \\
(V)\end{array}$ & $\begin{array}{l}i_{p} / 10^{-6} \\
\text { A.cm }\end{array}$ \\
\hline \multirow{4}{*}{$\begin{array}{c}p H=9 \\
\text { only }\end{array}$} & 298 & 1.39 & 0.95 & 0.135 & - & 0.437 & - & 0.78 & 1.13 \\
\hline & 303 & 1.26 & 1.00 & 0.240 & - & 0.250 & - & 0.69 & 1.14 \\
\hline & 308 & 1.23 & 1.08 & 0.448 & - & 0.136 & - & 0.67 & 1.15 \\
\hline & 313 & 1.22 & 1.10 & 0.480 & - & 0.129 & - & 0.63 & 1.16 \\
\hline \multirow{4}{*}{$\begin{array}{c}p H=9+ \\
1 \times 10^{-3} \mathrm{Cl}^{-}\end{array}$} & 298 & 1.40 & 9.852 & 0.052 & - & 1.137 & - & 0.43 & 0.197 \\
\hline & 303 & 1.35 & 10.837 & 0.078 & - & 0.771 & - & 0.41 & 0.207 \\
\hline & 308 & 1.26 & 11.823 & 0.081 & - & 0.754 & - & 0.39 & 0.212 \\
\hline & 313 & 1.22 & 12.510 & 0.099 & - & 0.627 & - & 0.38 & 0.222 \\
\hline \multirow{4}{*}{$\begin{array}{c}p H=9+ \\
1 \times 10^{-2} \mathrm{Cl}^{-}\end{array}$} & 298 & -0.01 & 0.788 & 0.375 & 0.251 & 0.158 & 0.236 & - & - \\
\hline & 303 & -0.03 & 0.837 & 0.176 & 0.262 & 0.342 & 0.229 & - & - \\
\hline & 308 & -0.06 & 0.887 & 0.143 & 0.276 & 0.427 & 0.221 & - & - \\
\hline & 313 & -0.07 & 1.182 & 0.097 & 0.301 & 0.640 & 0.206 & - & - \\
\hline \multirow{4}{*}{$\begin{array}{c}p H=9+ \\
0.1 C l^{-}\end{array}$} & 298 & 0.14 & 0.788 & 0.056 & 0.201 & 1.056 & 0.294 & - & - \\
\hline & 303 & 0.15 & 0.985 & 0.055 & 0.192 & 1.073 & 0.313 & - & - \\
\hline & 308 & 0.16 & 1.626 & 0.038 & 0.185 & 1.608 & 0.330 & - & - \\
\hline & 313 & 0.17 & 2.956 & 0.034 & 0.177 & 1.826 & 0.351 & - & - \\
\hline
\end{tabular}


Table (3)

Values of corrosion potentials $E_{c o r r}$,corrosion current densities $i_{c o r r}$ cathodic and anodic

Tafel slopes $\left(b_{c}\right.$ and $\left.b_{a}\right)$,cathodic and anodic transfer coefficients $\left(\alpha_{c}\right.$ and $\left.\alpha_{a}\right)$, passivity potentials $E_{p}$, and passivity current densities $i_{p}$, for the polarization of $A-M g$ alloy in aerated $1 \times 10^{-5}$ mol.dm ${ }^{-3} \mathrm{NaOH}$ solution in absence and presence of chloride ions at four temperatures.

\begin{tabular}{|c|c|c|c|c|c|c|c|c|c|}
\hline \multirow[b]{2}{*}{ Medium } & \multirow[b]{2}{*}{$\begin{array}{c}T \\
(K)\end{array}$} & \multicolumn{2}{|c|}{ Corrosion } & \multicolumn{2}{|c|}{$b\left(V_{\text {.decade }}^{-1}\right)$} & \multicolumn{2}{|c|}{$\alpha$} & \multicolumn{2}{|c|}{ Passivity } \\
\hline & & $\begin{array}{c}-E_{\text {corr }} \\
(V)\end{array}$ & $\begin{array}{c}i_{\text {corr }} / 10^{-6} \\
\text { A. } \mathrm{cm}^{-2}\end{array}$ & $-b_{c}$ & $+b_{a}$ & $\alpha_{c}$ & $\alpha_{a}$ & $\begin{array}{l}-E_{p} \\
(V)\end{array}$ & $\begin{array}{l}i_{p} / 10^{-6} \\
A . \mathrm{cm}^{-2}\end{array}$ \\
\hline \multirow{4}{*}{$\begin{array}{c}p H=9 \\
\text { only }\end{array}$} & 298 & 1.61 & 0.98 & 0.130 & - & 0.454 & - & 0.94 & 0.91 \\
\hline & 303 & 1.57 & 1.03 & 0.137 & - & 0.438 & - & 0.91 & 1.05 \\
\hline & 308 & 1.51 & 1.09 & 0.142 & - & 0.430 & - & 0.85 & 1.13 \\
\hline & 313 & 1.42 & 1.12 & 0.152 & - & 0.408 & - & 0.79 & 1.14 \\
\hline \multirow{4}{*}{$\begin{array}{c}p H=9+ \\
1 \times 10^{-3} \\
\mathrm{Cl}^{-}\end{array}$} & 298 & 1.80 & 11.07 & 0.042 & - & 1.408 & - & 0.50 & 0.552 \\
\hline & 303 & 1.71 & 17.99 & 0.065 & - & 0.925 & - & 0.44 & 0.589 \\
\hline & 308 & 1.65 & 23.91 & 0.081 & - & 0.754 & - & 0.42 & 0.607 \\
\hline & 313 & 1.50 & 27.13 & 0.101 & - & 0.615 & - & 0.40 & 0.626 \\
\hline \multirow{4}{*}{$\begin{array}{c}p H=9+ \\
1 \times 10^{-2} \\
\mathrm{Cl}^{-}\end{array}$} & 298 & 0.71 & 0.690 & 0.330 & 0.300 & 0.179 & 0.197 & - & - \\
\hline & 303 & 0.69 & 0.713 & 0.300 & 0.250 & 0.200 & 0.240 & - & - \\
\hline & 308 & 0.64 & 0.736 & 0.273 & 0.234 & 0.224 & 0.261 & - & - \\
\hline & 313 & 0.63 & 0.759 & 0.214 & 0.214 & 0.290 & 0.290 & - & - \\
\hline \multirow{4}{*}{$\begin{array}{c}p H=9+ \\
0.1 \mathrm{Cl}^{-}\end{array}$} & 298 & 0.79 & 0.828 & 0.231 & 0.230 & 0.256 & 0.257 & - & - \\
\hline & 303 & 0.80 & 0.966 & 0.220 & 0.215 & 0.273 & 0.279 & - & - \\
\hline & 308 & 0.83 & 1.000 & 0.214 & 0.188 & 0.286 & 0.325 & - & - \\
\hline & 313 & 0.88 & 1.381 & 0.188 & 0.136 & 0.330 & 0.457 & - & - \\
\hline
\end{tabular}

Table (4)

Values of corrosion potentials $E_{\text {corr }}$,corrosion current densities $i_{\text {corn }}$ cathodic and anodic Tafel slopes $\left(b_{c}\right.$ and $\left.b_{a}\right)$,cathodic and anodic transfer coefficients $\left(\alpha_{c}\right.$ and $\left.\alpha_{a}\right)$, passivity potentials $E_{p}$, and passivity current densities $i_{p}$, for the polarization of Al-Zn alloy in aerated $1 \times 10^{-5}$ mol.dm $^{-3} \mathrm{NaOH}$ solution in absence and presence of chloride ions at four temperatures.

\begin{tabular}{|c|c|c|c|c|c|c|c|c|c|}
\hline \multirow[b]{2}{*}{ Medium } & \multirow[b]{2}{*}{$\begin{array}{c}\boldsymbol{T} \\
(\boldsymbol{K})\end{array}$} & \multicolumn{2}{|c|}{ Corrosion } & \multicolumn{2}{|c|}{ b (V.decade $\left.{ }^{-I}\right)$} & \multicolumn{2}{|c|}{$\alpha$} & \multicolumn{2}{|c|}{ Passivity } \\
\hline & & $\begin{array}{c}-E_{c o r r} \\
(V) \\
\end{array}$ & $\begin{array}{c}i_{\text {corr }} / 10^{-6} \\
\text { A.cm }^{-2} \\
\end{array}$ & $-b_{c}$ & $+b_{a}$ & $\alpha_{c}$ & $\alpha_{a}$ & $\begin{array}{l}-E_{p} \\
(V) \\
\end{array}$ & $\begin{array}{l}i_{p} / 10^{-6} \\
\text { A. } \mathrm{cm}^{-2} \\
\end{array}$ \\
\hline \multirow{4}{*}{$\begin{array}{c}p H=9 \\
\text { only }\end{array}$} & 298 & 1.72 & 1.04 & 0.140 & - & 0.422 & - & 1.10 & 0.99 \\
\hline & 303 & 1.71 & 1.11 & 0.156 & - & 0.385 & - & 0.99 & 1.07 \\
\hline & 308 & 1.60 & 1.15 & 0.160 & - & 0.381 & - & 0.98 & 1.14 \\
\hline & 313 & 1.50 & 1.18 & 0.171 & - & 0.363 & - & 0.97 & 1.51 \\
\hline \multirow{4}{*}{$\begin{array}{c}p H=9+ \\
1 \times 10^{-3} \\
\mathrm{Cl}^{-}\end{array}$} & 298 & 2.02 & 21.82 & 0.188 & - & 0.314 & - & 1.25 & 0.588 \\
\hline & 303 & 2.00 & 22.99 & 0.214 & - & 0.281 & - & 1.21 & 0.602 \\
\hline & 308 & 1.92 & 24.22 & 0.273 & - & 0.224 & - & 1.18 & 0.612 \\
\hline & 313 & 1.85 & 27.68 & 0.550 & - & 0.113 & - & 1.16 & 0.633 \\
\hline \multirow{4}{*}{$\begin{array}{c}p H=9+ \\
1 \times 10^{-2} \\
\mathrm{Cl}^{-}\end{array}$} & 298 & 2.15 & 13.84 & 0.022 & - & 2.687 & - & 1.45 & 0.450 \\
\hline & 303 & 2.13 & 20.76 & 0.063 & - & 0.954 & - & 1.42 & 0.554 \\
\hline & 308 & 1.84 & 38.06 & 0.107 & - & 0.571 & - & 1.24 & 0.657 \\
\hline & 313 & 1.76 & 44.98 & 0.150 & - & 0.414 & - & 1.18 & 0.757 \\
\hline \multirow{4}{*}{$\begin{array}{c}p H=9+ \\
0.1 \mathrm{Cl}^{-}\end{array}$} & 298 & 1.06 & 0.832 & 0.045 & 0.059 & 1.314 & 1.002 & - & - \\
\hline & 303 & 1.07 & 0.971 & 0.111 & 0.103 & 0.542 & 0.584 & - & - \\
\hline & 308 & 1.19 & 1.103 & 0.167 & 0.120 & 0.366 & 0.509 & - & - \\
\hline & 313 & 1.21 & 1.517 & 0.178 & 0.130 & 0.349 & 0.478 & - & - \\
\hline
\end{tabular}




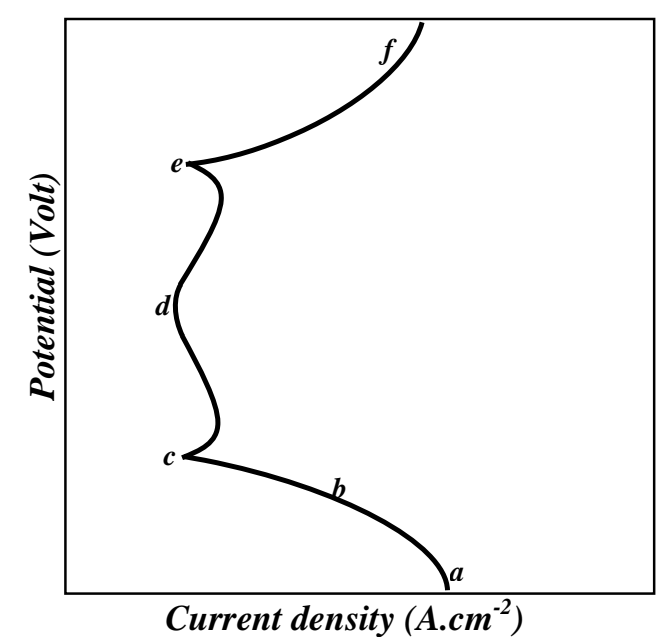

Fig. (4): The Typical Polarization Curve for Corrosion of Al-alloys in $\mathrm{NaOH}$ solution at $\mathrm{pH}=9$ at $289 \mathrm{~K}$.

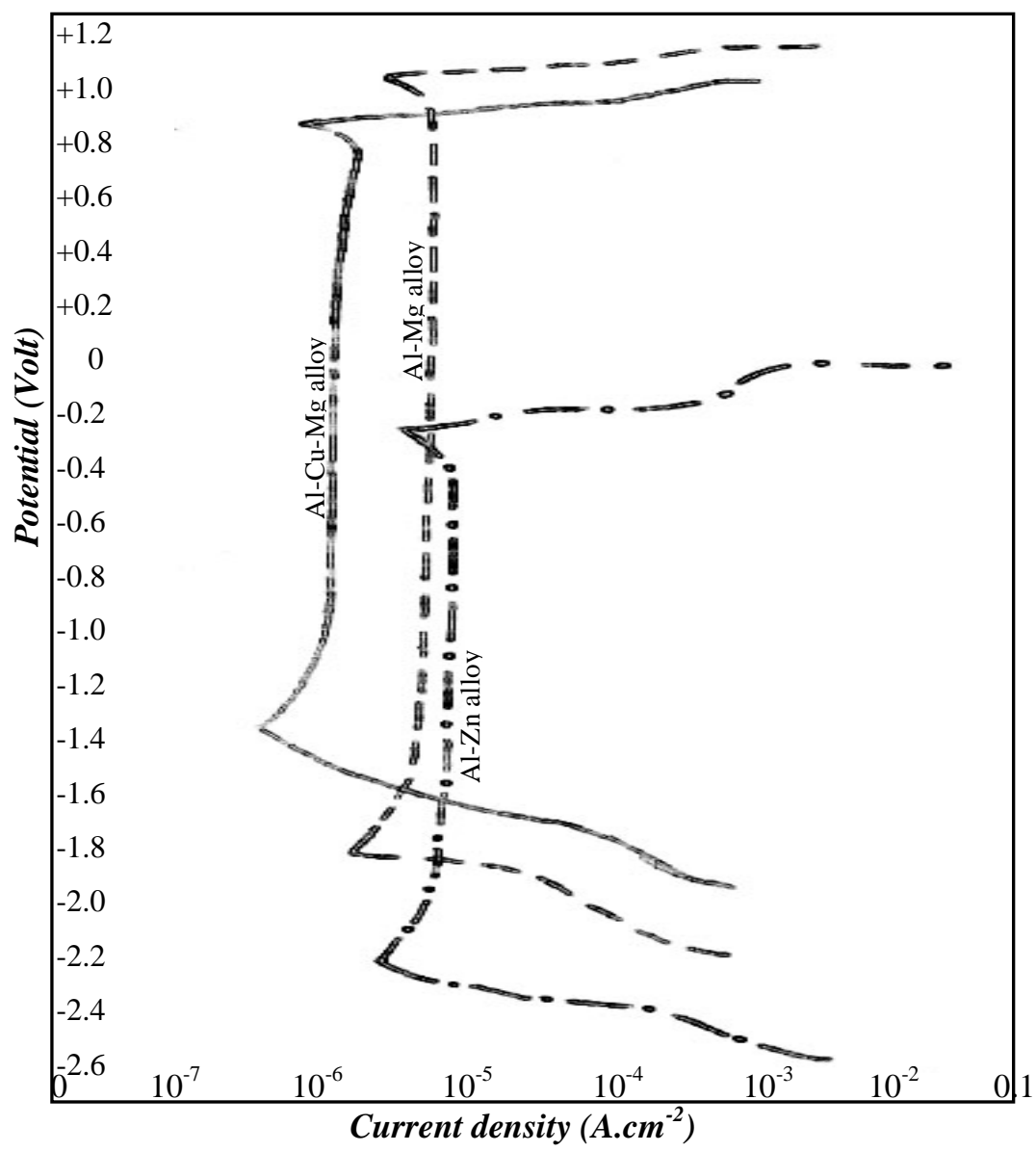

Fig. (5): The Polarization Curve for Corrosion of Al-alloys in $\mathrm{NaOH}$ solution at $\mathrm{pH}=9$ in the presence of $1 \times 10^{-3} \mathrm{~mol}_{\mathrm{dm}}{ }^{-3} \mathrm{Cl}^{-}$at $289 \mathrm{~K}$. 


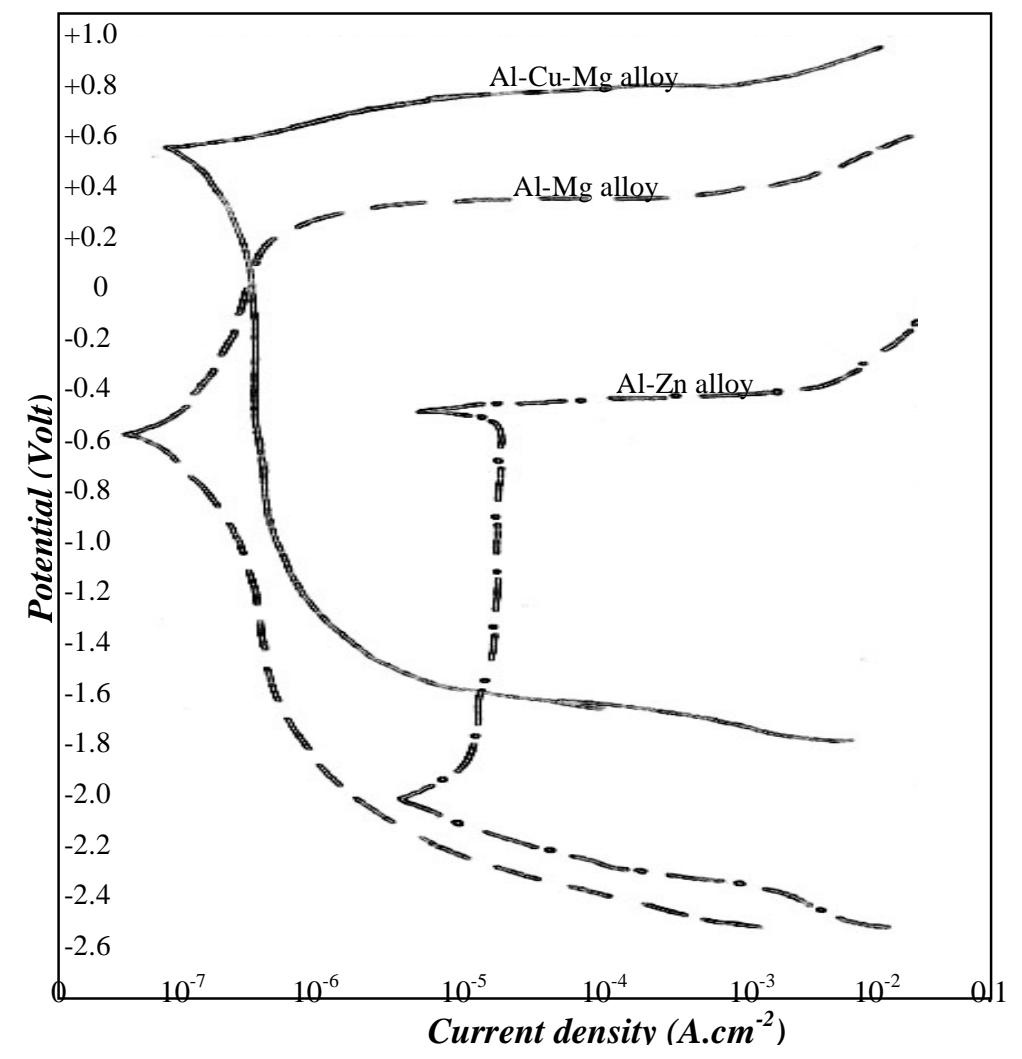

Fig. (6): The Polarization Curve for Corrosion of Al-alloys in $\mathrm{NaOH}$ solution at $\mathrm{pH}=9$ in the presence of $1 \times 10^{-2} \mathrm{~mol} . \mathrm{dm}^{-3} \mathrm{Cl}^{-}$at $289 \mathrm{~K}$.

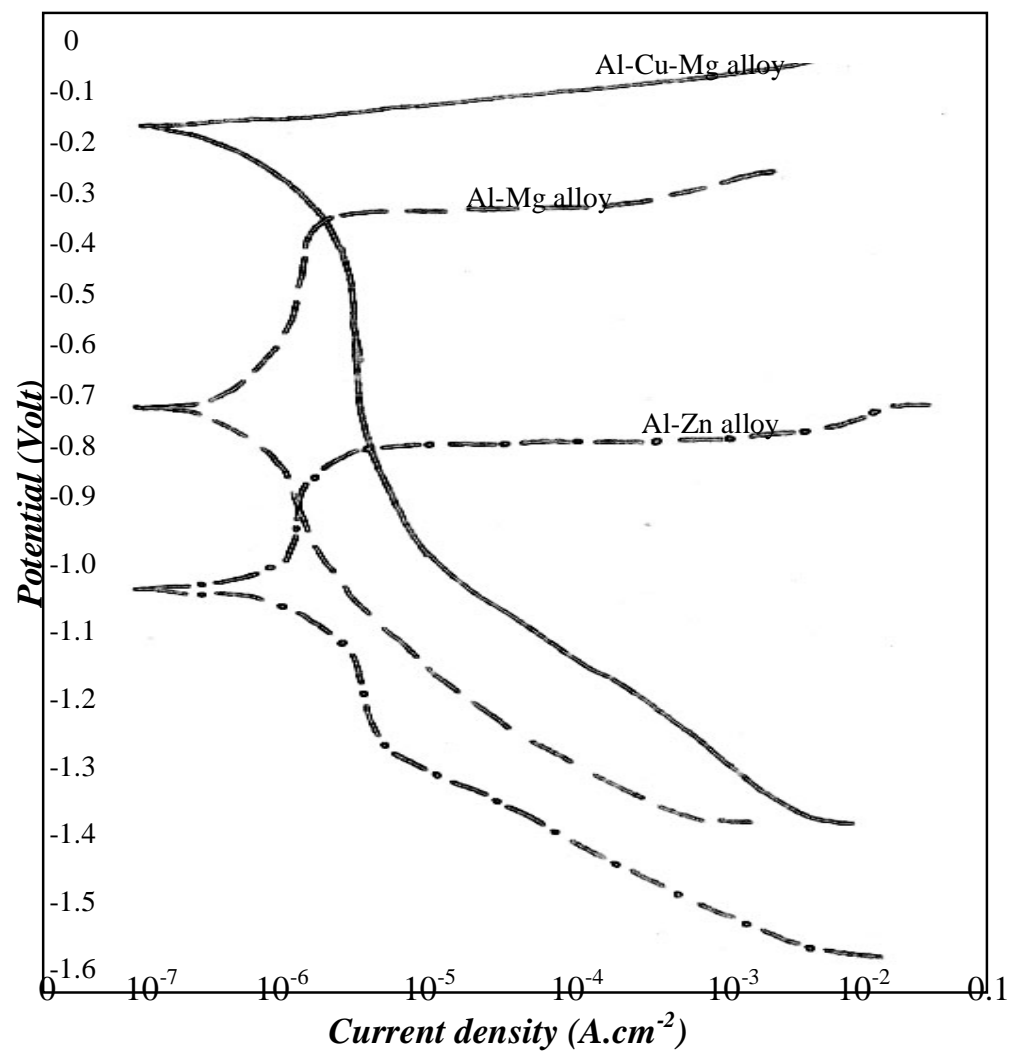

Fig. (7): The Polarization Curve for Corrosion of Al-alloys in $\mathrm{NaOH}$ solution at $\mathrm{pH}=9$ in the presence of $0.1 \mathrm{~mol} . \mathrm{dm}^{-3} \mathrm{Cl}^{-}$at $289 \mathrm{~K}$. 


\section{References}

[1] J. R. Davis, "Metal Handbook", second edition, 1998, pp. 488.

[2] K. Nisancioglu and H. Holtan, "Measurement of the critical pitting potential of aluminium", Corrosion Sci., Vol.18, 1978, pp.835-849.

[3] K. Nisancioglu and H. Holtan, "The protection potential of aluminium", Corrosion Sci., Vol.18, 1978, pp.10111023.

[4] S. H. Sanad, A. A. Ismail, K. M. El-Sobki and L. A. Shalaby, "Corrosion of Al-Mg alloys in sodium chloride solutions", Corrosion Prev. and Cont., Vol.29, No.21, June 1982, pp.21-23.

[5] Boguslaw Mazurkiewz, "The electrochemical behaviour of the $\mathrm{Al}_{8} \mathrm{Mg}_{5}$ intermetallic compound", Corrosion Sci., Vol.23, No.7, 1983, pp.687-690.

[6] E. Lunarska, and Z. Szklarska Smialowska, "Electrochemical study of the pitting corrosion of aluminium and its alloys-I. Determination of critical pitting and protection potentials", Corrosion nace, Vol.43, No.6, June 1987, pp.353359.

[7] A. Alavi and R.A. Cottis, "The determination of $\mathrm{pH}$, potential and chloride concentration in corroding crevices on 304 stainless steel and 7475 aluminium alloy", Corrosion Sci., Vol.27, No.5, 1987, pp.443-451.

[8] L. Tomesanyi, K. Varga, I. Bartik, G. Horanyi and E. Maleczki, "Electrochemical study of the pitting corrosion of aluminium and its alloys-II. Study of the interaction of chloride ions with a passive film on aluminium and initiation of pitting corrosion", Electrochimica Acta, Vol.34, No.6, 1989, pp.855-859.

[9] M. elboujdaini and E. Ghali, "An electrochemical investigation of the behaviour of aluminium alloys in different electrolytes", Corrosion Sci., Vol.30, No.8/9, 1990, pp.855-867.

[10] S. B. Saidman, S. G. Garcia and J. B. Bessone, "Electrochemical behaviour of Al-In alloys in chloride solutions", J. Appl. Electro., Vol.25, No.3, March 1995, pp.252-258.
[11] J. William, D. Jeremy, L. Richard, and S. Gerald, "A galvanic corrosion approach to investigation chromate effects on aluminium alloy 2024-T3", J. Electro. Soc., Vol.149, No.5, 2002, pp.179-185.

[12] L. L. Sherir, "Corrosion", Metal/ Environment Reactions, second ed., vol.1, 1976, pp. 4:12.

[13] Zaki Ahmed, "The kinetics of anodic and cathodic polarization of aluminium and its alloys", Anti- Corrosion, Vol., November 1986, pp.4-11.

[14] F.M. Mahdi, Thesis "Pitting corrosion characteristics of aluminium alloys", University of Technology-Department of production engineering and metallurgy", 1985.

[15] M. Metikos-Hukovic, R. Babic, Z. Grubac, and Brinc, "Inhibition of the hydrogen evolution reaction on aluminium covered by 'spontaneous' oxide", J. Appl. Electro., Vol.24,1994, pp.325-331.

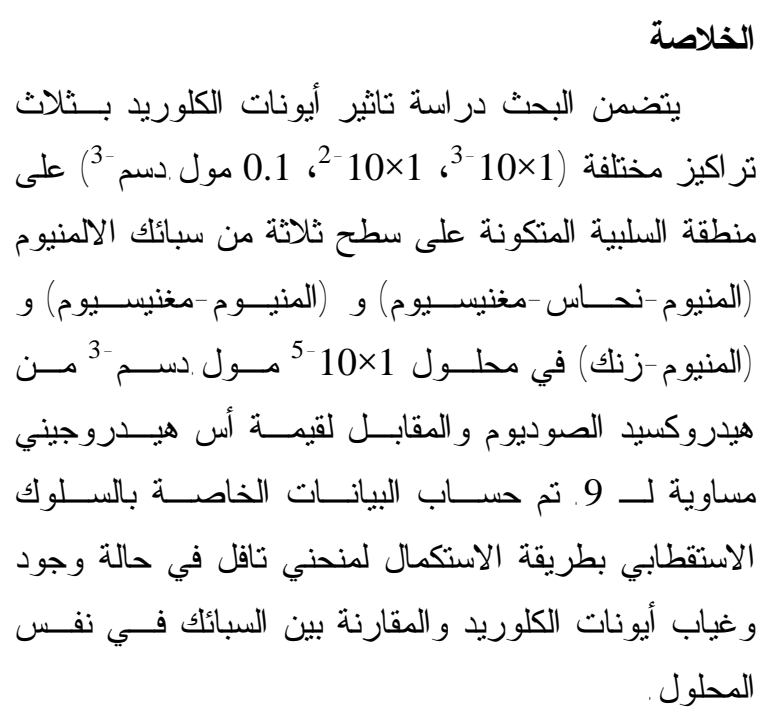

